\title{
Mística Cristã e Literatura Fantástica: a experiência mística em C. S. Lewis e a literatura fantástica como caminho da mística cristã
}

Orientadora: Lúcia Pedrosa de Pádua

Doutoranda: Márcio Simão de Vasconcellos

Área de Concentração: Teologia Sistemático-Pastoral

Linha de Pesquisa: Religião e Modernidade

Projeto de Pesquisa: Mística e Teologia e Humanização

Esta tese busca relacionar mística cristã, que é o fundamento da própria teologia, e literatura fantástica compreendendo esta como lugar tanto da teologia como da experiência mística. Afirmamos, portanto, que a literatura fantástica constitui uma forma de expressão da mística cristã. O que há em comum entre as definições desses conceitos é a dimensão do mistério que ambos compartilham. Pois, por um lado, a mística nos lembra da inefabilidade divina, diante da qual toda expressão da linguagem, embora necessária à sistematização da fé, revela-se insuficiente, uma vez que a experiência de Deus ultrapassa os limites do conhecimento racional-lógico da realidade. Por outro lado, a literatura fantástica introduz no mundo cotidiano a dimensão do insólito, do fantástico, do maravilhoso que enriquece a própria vida. Ambas traduzem experiências que são inquietantes e fundamentais à vida humana. Estas experiências inquietantes estão intimamente vinculadas à dimensão teológica e mística da existência. Por isso, a literatura fantástica é capaz de transmitir experiências profundamente humanas, incluindo as experiências teológicas e místicas. A partir dessa relação, o objetivo é investigar a experiência pessoal e algumas obras ficcionais do escritor irlandês C. S. Lewis a fim de perceber como, seja em sua vida, seja em sua produção literária, Lewis aborda questões vinculadas à mística cristã e à teologia por meio do uso da literatura fantástica.

Palavras-chave: Mística cristã. Teologia. Literatura Fantástica. 